\title{
DUKUNGAN SUAMI TERHADAP DETEKSI DINI KANKER SERVIKS PADA PASANGAN USIA SUBUR (PUS) DI DUSUN NGASEM DESA TIMBULHARJO SEWON BANTUL TAHUN 2016
}

Fatimah Dewi Anggraeni ${ }^{1}$, Klesia Benedikta ${ }^{1}$

${ }^{1}$ Program Studi Kebidanan Stikes Jenderal Achmad Yani Yogyakarta, Jl. Ringroad Barat Ambarketawang, Gamping, Sleman. Telp.(02744342000), Email: dewianggraeni303@gmail.com

\section{ABSTRACT}

Background: One of the purposes of Sustainable Development Goals (SDGs) is promoting health with a target to reduce one-third of deaths from non-communicable diseases through prevention. Cervical cancer is a malignant tumor that grows in the cervix or uterus that comes from $90 \%$ of squamous cells lining the cervix and the remaining $10 \%$ comes from mucus-producing gland cells in the cervical canal leading into the uterus. Cervical cancer is the second killer of women worldwide after breast cancer. One effort to reduce cervical cancer is by conducting an early detection.

Objectives: To investigate husbands' support for early detection of cervical cancer in fertile-aged couples in Ngasem Timbulharjo Sewon Bantul

Methods: This research was descriptive quantitative, with accindental sampling, involving 30 respondents aged 15-49 years old. Data were collected with a questionnaire and were analyzed using univariate analysis.

Results: Husbands' informational support was in low category (66.7\%), assesment support was low $(60.0 \%)$, instrumental support was low (53.3\%), and emotional support was also low (63.3\%).

Conclusion: Husbands' supports for early detection of cervical cancer were all in the low category.

Keywords: Husband's Support, Early Detection of Cervical Cancer

\section{PENDAHULUAN}

Target Sustainable Development Goals

(SDGs) yang ke-3 bertujuan untuk meningkatkan kesehatan yang baik dengan target yang akan dicapai yaitu mengurangi sepertiga kematian akibat penyakit tidak menular seperti Hipertensi, Jantung, Diabetes Mellitus, Kanker, Asma dan Penyakit Paru melalui pencegahan sampai tahun 2030. Salah satu upaya mengurangi kanker serviks yaitu dengan melakukan deteksi dini kanker serviks ${ }^{(1)}$.

Kanker Serviks adalah tumor ganas yang tumbuh di dalam serviks atau leher rahim yang berasal dari $90 \%$ sel skuamosa yang melapisi serviks dan $10 \%$ sisanya berasal dari sel kelenjar penghasil lendir pada saluran servikal yang menuju ke dalam Rahim. ${ }^{(2)}$

Indonesia merupakan negara kedua di dunia setelah Cina yang memiliki pengidap kanker serviks terbanyak. ${ }^{(3)}$ Angka kejadian kanker serviks di Indonesia tahun 2011 mencapai angka 100 per 100.000 penduduk per tahun, dan penyebarannya terakumulasi di Jawa dan Bali. ${ }^{(4)}$ Data Kementerian Kesehatan menunjukkan, tahun 2015 setiap jam jumlah penderita kanker serviks bertambah 2,5 orang dan korban meninggal 1,1 orang. Prevalensi penyakit kanker serviks di Indonesia pada tahun 2013, yaitu 0,8\% dengan 98.692 kasus dengan prevalensi tertinggi berada di Provinsi Daerah Istimewa Yogyakarta sebesar 1,5\% dengan 2703 kasus. ${ }^{(5)}$ 
Kanker serviks merupakan pembunuh wanita kedua di dunia setelah kanker payudara. ${ }^{(6)}$ Kanker serviks berkembang disebabkan oleh rendahnya cakupan deteksi kanker servik. Program deteksi dini di Indonesia masih kurang dari 5\%. ${ }^{(7)}$ Penderita kanker serviks pada umumnya akan datang ketika sudah stadium lanjut, hal ini terjadi karena kanker serviks biasanya tidak menimbulkan gejala awal yang jelas, tetapi bisa disembuhkan jika ditemukan secara dini dengan melakukan deteksi dini. ${ }^{(8)}$

Dukungan suami merupakan salah satu penyebab tingginya angka kejadian kanker serviks. Dukungan suami menjadi faktor penentu karena dukungan pasangan akan memberikan motivasi untuk melakukan pemeriksaan deteksi dini kanker serviks. Suami yang mempunyai pemahaman yang baik dapat memberikan penjelasan dan dukungannya pada istri untuk melaksanakan perilaku sehat. ${ }^{(9)}$

Puskesmas Sewon 1 Bantul merupakan puskesmas yang membawahi Desa Timbulharjo dan Desa Pendowoharjo, berdasarkan data Pemeriksaan di Puskesmas Sewon 1 pada tahun 2015 terdapat 6601 PUS. Pus yang melakukan pemeriksaan Inspeksi Visual Asam Asetat (IVA) yaitu 33 (0.49\%) orang dan pemeriksaan Pap Smear 32 $(0,48 \%)$ orang. Dusun Ngasem merupakan dusun dengan angka partisipasi pemeriksaan deteksi dini terendah di wilayah kerja Puskesmas Sewon 1. Partisipasi PUS dari Dusun Ngasem Pemeriksaan IVA 0 wanita dan
Pap Smear hanya 1 wanita.

Hasil studi pendahuluan di Dusun Ngasem, Desa Timbulharjo Kecamatan Sewon Bantul pada tanggal 10 Mei 2016, dari 20 WUS yang melakukan pemeriksaan dengan metode IVA hanya (15\%) 3 wanita dan (85\%) 17 wanita belum melakukan pemeriksaan. Dari 20 responden sebagian besar mendapat dukungan kurang (60\%) 12 wanita dan dukungan baik (40\%) 6 wanita. Berdasarkan uraian di atas, peneliti ingin meneliti tentang Gambaran dukungan suami tentang deteksi dini kanker serviks di Dusun Ngasem Desa Timbulharjo Kecamatan Sewon, Bantul, Yogyakarta

\section{BAHAN DAN CARA PENELITIAN}

Jenis penelitian ini menggunakan penelitian deskriptif kuantitatif. Penelitian ini menggambarkan dukungan suami terhadap deteksi dini kanker serviks pada pasangan usia subur di Dusun Ngasem Desa Timbulharjo, Sewon, Bantul, Yogyakarta

Populasi dalam penelitian ini adalah seluruh Pasangan Usia Subur (PUS) yang tinggal di Dusun Ngasem Desa Timbulharjo Sewon Bantul yaitu berjumlah 32 responden. Sampling dalam penelitian ini menggunakan metode sampling accidental. Jumlah sampel dalam penelitian ini menggunakan jumlah sampling minimal yaitu 30 wanita. Alat yang digunakan untuk pengumpulan data tentang dukungan suami tentang deteksi dini kanker serviks adalah kuesioner tertutup. Kuesioner dukungan suami disusun berdasarkan 
beberapa indikator, yaitu dukungan informasional, dukungan penilaian, dukungan instrumental, dan dukungan emosional.

\section{HASIL DAN PEMBAHASAN}

Tabel 1. Karakteristik Responden di Dusun Ngasem Desa Timbulharjo Sewon Bantul Karakteristik Frekuensi Persentase

(\%)

\begin{tabular}{|c|c|c|}
\hline \multicolumn{3}{|l|}{ Umur } \\
\hline Responden & & \\
\hline $20-35$ Tahun & 17 & $56.7 \%$ \\
\hline > 35 Tahun & 13 & $43.3 \%$ \\
\hline Jumlah & 30 & $100 \%$ \\
\hline \multicolumn{3}{|l|}{ Pendidikan } \\
\hline \multicolumn{3}{|l|}{ Responden } \\
\hline SD & 3 & $10.0 \%$ \\
\hline SMP & 4 & $13.3 \%$ \\
\hline SMA & 21 & $70.0 \%$ \\
\hline Perguruan Tinggi & 2 & $6.7 \%$ \\
\hline Jumlah & 30 & $100 \%$ \\
\hline \multicolumn{3}{|l|}{ Pekerjaan } \\
\hline \multicolumn{3}{|l|}{ Responden } \\
\hline Tidak Bekerja & 20 & $66.7 \%$ \\
\hline Swasta & 9 & $30.0 \%$ \\
\hline Wiraswasta & 1 & $3.3 \%$ \\
\hline Jumlah & 30 & $100 \%$ \\
\hline \multicolumn{3}{|l|}{ Umur Suami } \\
\hline $20-35$ Tahun & 25 & $83.3 \%$ \\
\hline > 35 Tahun & 5 & $16.7 \%$ \\
\hline Jumlah & 30 & $100 \%$ \\
\hline \multicolumn{3}{|l|}{ Pendidikan } \\
\hline \multicolumn{3}{|l|}{ Suami } \\
\hline SD & 1 & $3.3 \%$ \\
\hline SMP & 7 & $23.3 \%$ \\
\hline SMA & 20 & $66.7 \%$ \\
\hline Perguruan Tinggi & 2 & $6.7 \%$ \\
\hline Jumlah & 30 & $100 \%$ \\
\hline \multicolumn{3}{|l|}{ Pekeriaan Suami } \\
\hline Tidak bekerja & 1 & $3.3 \%$ \\
\hline Petani & 1 & $3.3 \%$ \\
\hline Swasta & 22 & $73.3 \%$ \\
\hline Wiraswasta & 4 & $13.3 \%$ \\
\hline PNS/TNI/POLRI & 2 & $6.7 \%$ \\
\hline Jumlah & 30 & $100 \%$ \\
\hline \multicolumn{3}{|l|}{ Pendapatan } \\
\hline \multicolumn{3}{|l|}{ Keluarga } \\
\hline$\leq$ Rp. 1.297 .700 & 26 & $86.7 \%$ \\
\hline$>$ Rp. 1.297 .700 & 4 & $13.3 \%$ \\
\hline Jumlah & 30 & $100 \%$ \\
\hline
\end{tabular}

Tabel 1 menunjukan bahwa umur responden sebagian besar adalah antara 2035 tahun yaitu $56.7 \%$ (17 responden). Tingkat pendidikan responden sebagian besar adalah SMA yaitu $70.0 \%$ (21 responden). Sebagian besar pekerjaan responden adalah tidak bekerja yaitu $66.7 \%$ (20 respendon). Umur suami responden sebagian besar antara 20-35 tahun yaitu $83.3 \%$ (25 responden)) Tingkat pendidikan suami responden sebagian besar adalah SMA yaitu $66.7 \%$ (20 responden). Sebagian besar pekerjaan suami responden adalah swasta yaitu $73.3 \%$ (22 responden). Rata-rata pendapatan keluarga adalah $<$ Rp. 1.297 .700 yaitu $86.7 \%$ (26 keluarga)

\begin{tabular}{lcc}
$\begin{array}{c}\text { Tabel 2. Pemeriksaan Deteksi Dini Kanker } \\
\text { Serviks di Dusun Ngasem Desa } \\
\text { Timbulharjo Sewon Bantul }\end{array}$ \\
\hline Pemeriksaan & Frekuensi & $\begin{array}{c}\text { Persentase } \\
(\%)\end{array}$ \\
\hline Tidak periksa & 24 & $80.0 \%$ \\
Pap Smear & 4 & $13.3 \%$ \\
IVA & 2 & $6.7 \%$ \\
\hline Jumlah & 30 & $100 \%$ \\
\hline
\end{tabular}

Berdasarkan tabel 2 dapat diketahui bahwa sebanyak 24 responden atau $80.0 \%$ responden tidak pernah melakukan deteksi dini kanker serviks.

\begin{tabular}{lcc}
$\begin{array}{l}\text { Tabel 3. Dukungan Suami Terhadap Deteksi } \\
\text { Dini Kanker Serviks di Dusun Ngasem } \\
\text { Desa Timbulharjo Sewon Bantul }\end{array}$ \\
\hline \multicolumn{1}{c}{ Kategori } & Frekuensi & $\begin{array}{c}\text { Persentase } \\
(\%)\end{array}$ \\
\hline Kurang & 19 & $63.3 \%$ \\
Baik & 11 & $36.7 \%$ \\
\hline Jumlah & 30 & $100 \%$ \\
\hline
\end{tabular}

Berdasarkan tabel 3 dapat diketahui bahwa dukungan suami terhadap deteksi dini kanker serviks di RT I Dusun Ngasem Desa Timbulharjo Sewon Bantul 
menunjukkan dukungan kurang yaitu 19 responden (63.3\%).

Tabel 4. Dukungan Informasional Suami Terhadap Deteksi Dini Kanker Serviks di Dusun Ngasem

Desa Timbulharjo Sewon Bantul

\begin{tabular}{lcc}
\hline \multicolumn{1}{c}{ Kategori } & Frekuensi & Persentase (\%) \\
\hline Kurang & 20 & $66.7 \%$ \\
Baik & 10 & $33.3 \%$ \\
\hline Jumlah & 30 & $100 \%$ \\
\hline
\end{tabular}

Berdasarkan tabel 4 dapat diketahui

bahwa dukungan informasional suami terhadap deteksi dini kanker serviks di RT I Dusun Ngasem Desa Timbulharjo Sewon Bantul menunjukkan dukungan kurang yaitu 20 responden (66.7\%).

Tabel 5. Dukungan Penilaian Suami Terhadap Deteksi Dini Kanker Serviks di Dusun Ngasem

Desa Timbulharjo Sewon Bantul

\begin{tabular}{lcc}
\hline \multicolumn{1}{c}{ Kategori } & Frekuensi & $\begin{array}{c}\text { Persentase } \\
(\%)\end{array}$ \\
\hline Kurang & 18 & $60.0 \%$ \\
Baik & 12 & $40.0 \%$ \\
\hline Jumlah & 30 & $100 \%$ \\
\hline
\end{tabular}

Berdasarkan tabel 5 dapat diketahui bahwa dukungan penilaian suami terhadap deteksi dini kanker serviks di RT I Dusun Ngasem Desa Timbulharjo Sewon Bantul menunjukkan dukungan kurang yaitu 18 responden (60.0\%).

Berdasarkan tabel 6 dapat diketahui bahwa dukungan instrumental suami terhadap deteksi dini kanker serviks di RT I Dusun Ngasem Desa Timbulharjo Sewon Bantul menunjukkan dukungan kurang yaitu 16 responden (53.3\%).
Tabel 6. Dukungan Instrumental Suami Terhadap Deteksi Dini Kanker Serviks di Dusun Ngasem Desa Timbulharjo Sewon Bantul

\begin{tabular}{|c|c|c|}
\hline Kategori & Frekuensi & $\begin{array}{c}\text { Persentase } \\
(\%)\end{array}$ \\
\hline Kurang & 16 & $53.3 \%$ \\
\hline Baik & 14 & $46.7 \%$ \\
\hline Jumlah & 30 & $100 \%$ \\
\hline \multicolumn{3}{|c|}{$\begin{array}{l}\text { Tabel 7. Dukungan Emosional Suami } \\
\text { terhadap Deteksi Dini Kanker Serviks } \\
\text { di Dusun Ngasem } \\
\text { Desa Timbulharjo Sewon Bantul }\end{array}$} \\
\hline Kategori & Frekuensi & Persentase $(\%)$ \\
\hline Kurang & 19 & $63.3 \%$ \\
\hline Baik & 11 & $36.7 \%$ \\
\hline Jumlah & 30 & 100 \\
\hline
\end{tabular}

Berdasarkan tabel 7 dapat diketahui bahwa dukungan emosional suami terhadap deteksi dini kanker serviks di RT I Dusun Ngasem Desa Timbulharjo Sewon Bantul menunjukkan dukungan kurang yaitu 19 responden atau $63.3 \%$.

Berdasarkan hasil penelitian diketahui bahwa sebagian besar responden tidak melakukan deteksi dini kanker serviks yaitu 24 responden atau $80.0 \%$. Hasil penelitian ini serupa dengan penelitian yang dilakukan oleh Salmadengan judul "Faktor Dominan yang Berhubungan Dengan Perilaku Pemeriksaan Pap Smear pada Wanita Usia Subur di Perumahan Graha Prima Kabupaten Bekasi Jakarta Timur" menunjukkan sebanyak 36 responden atau $72 \%$ tidak melakukan Pap Smear. ${ }^{(10)}$

Hasil penelitian Linandi dengan judul 
"Dukungan Suami Mendorong

Keikutsertaan Pap Smear Pasangan Usia Subur (PUS) di Perumahan Pucang Gading Semarang" menjelaskan bahwa apabila responden memiliki kesadaran dan minat terhadap Pap Smear dari diri sendiri disertai dengan adanya dukungan dari suami secara signifikan dapat meningkatkan keinginan wanita untuk melakukan praktik Pap Smear. ${ }^{(11)}$

Hasil penelitian ini didukung oleh teori yang dikemukakan oleh Emilia yang menyatakan bahwa masalah lain dalam melakukan screening kanker serviks ialah wanita enggan diperiksa karena malu. Penyebab lain ialah kerepotan, keraguan akan pentingnya pemeriksaan, kurangnya pengetahuan tentang pentingnya pemeriksaan, takut terhadap kenyataan hasil pemeriksaan, takut merasa sakit pada pemeriksaan, rasa segan diperiksa oleh dokter pria, dan kurangnya dorongan keluarga terutama suami. ${ }^{(12)}$

Berdasarkan hasil penelitian diketahui bahwa dukungan suami terhadap deteksi dini kanker serviks di RT I Dusun Ngasem Desa Timbulharjo Sewon Bantul adalah dukungan kurang sebanyak 19 responden atau $63.3 \%$.

Bentuk dukungan suami dapat berupa pemberian informasi tentang kanker serviks, memberikanrespon atau tanggapan yang positif jika responden mengajak diskusi tentang masalah kesehatan wanita salah satunya kanker serviks. Suami yang merespon baik biasanya akan diikuti dengan pemberian dukungan berupa uang untuk biaya pemeriksaan dan suami menyatakan tidak keberatan bila responden minta diantar ke tempat periksa Pap Smear/IVA. Sebagian besar suami yang mendukung justru memiliki inisiatif terlebih dahulu untuk memotivasi responden melakukan Pap Smear/IVA.

Hasil tabulasi berdasarkan dukungan suami dan deteksi dini kanker serviks dalam penelitian ini responden yang mendapatkan dukungan kurang sebagian besar tidak melakukan deteksi dini kanker serviks yaitu 18 responden atau $60.0 \%$. Kondisi ini sesuai dengan teori dari Green dalam Emilia menyebutkan salah satu faktor yang memengaruhi upaya deteksi dini kanker serviks yaitu dukungan keluarga atau suami. Suami adalah orang yang paling dekat dengan wanita, bahkan menjadi seorang yang dapat memengaruhi keputusan yang diambil seorang wanita. ${ }^{(12)}$

Dukungan suami adalah bentuk dukungan sosial sebagai respon yang dapat dirasakan dan bermanfaat oleh anggota keluarga. Oleh karena itu, suami yang mendukung istrinya melakukan Pap 
Smear dapat menjadi pendorong bagi seorang wanita untuk berpartisipasi dalam pemeriksaan Pap Smear atau IVA.

Berdasarkan hasil penelitian diketahui bahwa dukungan informasional suami terhadap deteksi dini kanker serviks di RT I Dusun Ngasem Desa Timbulharjo Sewon Bantul adalah dukungan kurang sebanyak 20 responden atau $66.7 \%$.

Berdasarkan analisis kuesioner didapatkan hasil yaitu dukungan kurang dalam dukungan informasional yaitu suami tidak memberikan pendapat tentang pentingnya pemeriksaan, suami tidak menganjurkan ibu untuk melakukan pemeriksaan, suami tidak menegur jika istri tidak melakukan pemeriksaan, suami tidak menjelaskan manfaat pemeriksaan, dan suami tidak mengingatkan waktu pelaksaan pemeriksaan tersebut. Hal ini menyebabkan dukungan informasional yang diberikan suami kurang karena dalam dukungan informasional tersebut suami seharusnya bertindak sebagai pemberi informasi baik secara langsung yang sudah dijelaskan melalui buku/majalah, suami memberikan saran digunakan untuk mengungkapkan suatu masalah, suami memberi nasihat maupun memberikan petunjuk. ${ }^{(13)}$

Dukungan infomasional menambah pengetahuan seseorang dalam mencari jalan keluar atau memecahkan masalah seperti nasihat atau pengarahan. Suami yang memberikan informasi bagi istrinya menyebabkan ibu akan terpapar informasi mengenai deteksi dini kanker serviks. ${ }^{(14)}$

Berdasarkan hasil penelitian diketahui bahwa dukungan penilaian suami terhadap deteksi dini kanker serviks di RT I Dusun Ngasem Desa Timbulharjo Sewon Bantul adalah dukungan kurang sebanyak 18 responden atau $60.0 \%$. Berdasarkan analisis kuesioner didapatkan hasil dukungan kurang dalam dukungan penilaian yaitu suami tidak memberikan pujian kepada istri setelah melakukan pemeriksaan, suami tidak memberikan respon terhadap pemeriksaan dan suami tidak menenangkan ibu saat ibu dalam kondisi sedih atau takut untuk melakukan pemeriksaan.

Kondisi ini menyebabkan dukungan penilaian yang diberikan kurang karena wujud dari dukungan penilaian yaitu suami memberikan penghargaan atas usaha yang dilakukan istri, memberikan umpan balik mengenai hasil atau prestasi yang dicapai, dan memberikan penilaian positif dan penilaian negatif yang pengaruhnya sangat berarti bagi seseorang. ${ }^{(15)}$ Dalam dukungan ini suami bertindak sebagai pemberi umpan balik, membimbing dan menengahi pemecahan masalah, sebagai 
sumber dan validator indentitas anggota keluarga di antaranya memberikan support, penghargaan, dan perhatian. ${ }^{(16)}$

Berdasarkan hasil penelitian diketahui bahwa dukungan instrumental suami terhadap deteksi dini kanker serviks di RT I Dusun Ngasem Desa Timbulharjo Sewon Bantul adalah dukungan kurang sebanyak 16 responden atau 53.3\%. Berdasarkan hasil analisis kuesioner didapatkan hasil dukungan kurang dalam dukungan instrumental yaitu suami tidak memberikan biaya untuk pemeriksaan, suami tidak menyediakan kendaraan untuk melakukan pemeriksaan, dan suami tidak menyediakan asuransi BPJS untuk pemeriksaan.

Kondisi tersebut menyebabkan kurangnya dukungan yang diberikan suami berkaitan dengan dukungan instrumental, karena dukungan instrumental tersebut berupa bantuan yang diberikan secara langsung. Dalam dukungan ini suami menyediakan fasilitas yang dibutuhkan, memberi pinjaman uang kepada istri, serta memberikan peluang waktu untuk menemani istri ketika memeriksakan kesehatannya. Bantuan instrumental bertujuan untuk mempermudah seseorang dalam melakukan aktivitasnya berkaitan dengan persoalan-persoalan yang dihadapinya. ${ }^{(17)}$
Berdasarkan hasil penelitian diketahui bahwa dukungan emosional suami terhadap deteksi dini kanker serviks di RT I Dusun Ngasem Desa Timbulharjo Sewon Bantul adalah dukungan kurang sebanyak 19 responden atau $63.3 \%$. Berdasarkan hasil analisis kuesioner diketahui bahwa dukungan kurang dalam dukungan emosional yaitu suami tidak memberikan kepercayan untuk melakukan pemeriksaan, suami tidak peduli akan pemeriksaan, suami tidak memperhatikan kondisi istri, dan istri tidak nyaman ketika suami mendampingi saat melakukan pemeriksaan. Kondisi ini menyebabkan kurangnya dukungan emosional yang diberikan karena dukungan emosional tersebut berupa ungkapan empati, perhatian, maupun kepedulian serta persetujuan. Dukungan Emosional membuat individu memiliki perasaan aman, nyaman, berharga, yakin dan diperdulikan, merasa dicintai. ${ }^{(18)}$

\section{KESIMPULAN}

Dukungan suami terhadap deteksi dini kanker serviks di Dusun Ngasem Desa Timbulharjo Sewon Bantul dalam kategori kurang sebanyak 19 responden (63.3\%). Persentase responden yang tidak pernah melakukan deteksi dini kanker serviks serviks di Dusun Ngasem Desa 
Timbulharjo Sewon Bantul adalah 24 responden $(80.0 \%)$.

Dukungan

informasional suami terhadap deteksi dini kanker serviks di Dusun Ngasem Desa Timbulharjo Sewon Bantul dalam kategori kurang sebanyak 20 responden (66.7\%). Dukungan penilaian suami terhadap deteksi dini kanker serviks di Dusun Ngasem Desa Timbulharjo Sewon Bantul dalam kategori kurang sebanyak 18 responden (60.0\%). Dukungan instrumental suami terhadap deteksi dini kanker serviks di Dusun Ngasem Desa Timbulharjo Sewon Bantul dalam kategori kurang sebanyak 16 responden (53.3\%). Dukungan emosional suami terhadap deteksi dini kanker serviks di Dusun Ngasem Desa Timbulharjo Sewon Bantul dalam kategori kurang sebanyak 19 responden (63.3\%).

Peneliti menyarankan kepada tenaga kesehatan hendaknya melakukan penyuluhan dan pendidikan kesehatan mengenai deteksi dini kanker serviks tidak hanya pada kelompok ibu, namun juga kepada suami agar mereka mengerti pentingnya deteksi dini kanker serviks pada pasangan usia subur, sehinga suami bisa memberikan dukungan kepada istri untuk melakukan deteksi dini kanker serviks.

\section{KEPUSTAKAAN}

1. Kemenkes. Kesehatan Dalam Kerangka Sustainable Development Goals (Sdgs). Jakarta: Kemenkes RI. 2015.

2. Nugroho,T.Masalah Kesehatan Reproduksi Wanita. Yogyakarta: Nuha Medika. 2014.

3. Ghofar, A. Cara Mudah Mengenal dan Mengobati Kanker . Yogyakarta: Flamingo. 2009.

4. Rasjidi, I. Vaksin Human Pappiloma Virus dan Eradikasi Kanker Mulut Rahim. Malang: Sagung Seto. 2006

5. Kemenkes. Pusat Data Informasi Kementrian Kesehatan RI. Jakarta: Kemenkes RI. 2015.

6. Wijaya, D. Pembunuh Ganas Itu Bernama Kanker Serviks. Yogyakarta: Sinar Kejora. 2010.

7. Samadi, H. Kanker Serviks. Jakarta: PT Tiga Serangkai Pustaka Mandiri. 2010.

8. Romauli, S. Vindari, A.M. Kesehatan Reproduksi buat Mahasiswi Kebidanan. Yogyakarta: Nuha Medika. 2009.

9. Setiadi. Konsep dan Proses Keperawatan Keluarga. Surabaya : Graha ilmu. 2008.

10. Salma, dkk. Faktor dominan yang berhubungan dengan perilaku pemeriksaan Pap Smear pada Wanita Usia Subur (WUS) di Perumahan Graha Prima Kabupaten Bekasi. Jurnal IImu dan Teknologi Kesehatan. Vol.1 No.1. Jakarta: Poltekes Kemenkes Jakarta III. 2013.

11. Linadi, K. Dukungan Suami Mendorong Keikutsertaan Pap Smear Pasangan Usia Subur (PUS) di Perumahan Pucang Gading Semarang. Jurnal Kesehatan Reproduksi. Vol.4 No.2. Semarang: Universitas Diponegoro. 2013. 
12. Emilia, O. Bebas Ancaman Kanker Serviks. Yogyakarta: Media Pressindo. 2010.

13. Friedman, dkk. Buku ajar keperawatan keluarga: Riset, Teori dan praktik Edisi 5. Jakarta: EGC. 2010.

14.Ratna, W. Sosiologi dan Antropologi Kesehatan. Yogyakarta: Pustaka Rihama. 2009.

15.Setiadi. Konsep dan Proses Keperawatan Keluarga. Surabaya : Graha ilmu. 2008.

16. Harmoko. Asuhan Keperawatan Keluarga. Yogyakarta: Pustaka Pelajar. 2012.
17.Ratna, W. Sosiologi dan Antropologi Kesehatan. Yogyakarta: Pustaka Rihama. 2009.

18.Fitriani, KI. Kajian Teori Sumber Dukungan Keluarga. Tesis. Malang: Universitas Islam Negeri Maulana Malik Ibrahim. 2011 